\title{
PENGARUH KARAKTERISTIK TUJUAN ANGGARAN TERHADAP TINGKAT PENYERAPAN ANGGARAN DENGAN PENGAWASAN INTERNAL SEBAGAI VARIABEL MODERATING
}

\author{
Santi Yustini \\ UIN Syarif Hidayatullah Jakarta
}

\begin{abstract}
$A B S T R A C T$
This study examines the effect of budgetary goal characteristics to budget realization rate with internal control as a moderating variable. Respondents in this study are head of division in the Islamic State University Syarif Hidayatullah Jakarta. Convenience sampling method used in this research, while multiple regression and moderate regression analysis used to data analizing.

The results show that budgetary participation, budgetary evaluation, budgetary feedback, budget goal clarity and budget goal difficulty simultaneously and significantly influence budget realization rate, and the result of analysis partially on an independent variable is not influencing to budget realization rate. And Internal control can't be a moderating variable for budgetary participation.
\end{abstract}

Keyword: Budgetary goal characteristics, internal control, budget realization rate

\section{PENDAHULUAN}

Istilah anggaran atau penganggaran (budgeting) sudah tidak asing lagi bagi mereka yang biasa berkecimpung dalam organisasi, termasuk organisasi pemerintahan. Anggaran merupakan salah satu bagian dari proses pengendalian manajemen yang berisi rencana tahunan yang dinyatakan secara kuantitatif, diukur dalam satuan moneter standar dan merupakan taksiran sumber daya yang diperlukan untuk melaksanakan program kerja. Kenis (1979) mengindikasi bahwa ada lima karakteristik dalam sistem penganggaran (budgetary goal characteristics). Dalam penelitiannya kelima karakteristik tersebut meliputi: partisipasi penyusunan anggaran, kejelasan sasaran anggaran, kesulitan sasaran anggaran, umpan balik anggaran dan evaluasi anggaran.

Dalam penyusunan anggaran diperlukan partisipasi yang merupakan keikutsertaan dalam penyusunan anggaran. Partisipasi ini diperlukan untuk memotivasi pelaksana dalam mencapai sasaran anggaran. Evaluasi anggaran dilakukan dengan membandingkan antara apa yang dianggarkan dengan apa yang dicapai. Adanya umpan balik dari pimpinan juga dapat menjadi motivasi tersendiri untuk pelaksana dalam merealisasikan anggaran, dan yang terpenting adalah anggaran yang disusun tersebut harus jelas baik dari sasaran atau output yang akan dicapai. Selain hal tersebut, dalam penyusunan anggaran juga harus memperhatikan tingkat kesulitan sasaran anggaran. Tingkat kesulitan sasaran anggaran ini tidak boleh terlalu mudah dan tidak terlalu sulit untuk dicapai oleh para pelaksana anggaran sehingga anggaran menjadi efektif untuk dicapai. Menurut Pidros (2012) menyatakan bahwa secara umum penyerapan APBN tahun 2011 tidak maksimal (under-spending). Di sisi lain, ketika mendekati akhir tahun, puncaknya bulan Desember, pembelanjaan melambung tinggi 
(over-spending). Pengaruhnya bukan saja pada masalah inflasi yang naik, melainkan efektivitas dan efisiensi kegiatan yang nampaknya boros tanpa memperhatikan output dan outcome-nya. Ironisnya, fenomena ini sudah menjadi masalah klasik dari tahun ke tahun.

Seperti sudah menjadi 'kebiasaan', pengeluaran belanja instansi pemerintah seringkali menumpuk pada dua bulan terakhir setiap tahunnya. Pada umumnya, porsi besar pengeluaran belanja barang dan jasa, dan belanja modal baru dilaksanakan pada bulan November dan Desember, walaupun pada akhirnya total realisasi penyerapan satu tahun menjadi besar (Pirdos dan Rawuh:2012). Sindrom akhir tahun anggaran ini cenderung buruk bagi kinerja birokrasi di Indonesia. Kinerja menjadi tidak efektif dan efisien, dampak pembangunan dan pertumbuhan di berbagai sektor menjadi tersendat, parahnya, anggaran dihambur-hamburkan dan cenderung tidak tepat sasaran.

Kondisi di atas menunjukkan adanya indikasi pengelolaan keuangan negara yang kurang baik. Rendahnya total penyerapan anggaran menjadi indikasi belum optimalnya peran pemerintah dalam memberikan kontribusi pada Pendapatan Domestik Brutto. Lebih lanjut hal ini menunjukkan sebagai kurang optimalnya peran pemerintah dalam mendorong pertumbuhan ekonomi. Dalam rangka upaya mereformasi bidang keuangan, pemerintah telah mengeluarkan 3 (tiga) paket perundang-undangan di bidang keuangan negara, yaitu Undang-Undang Nomor 17 Tahun 2004 tentang Keuangan Negara, Undang-Undang Nomor 1 Tahun 2004 tentang Perbendaharaan Negara dan Undang-Undang Nomor 15 Tahun 2004 tentang Pemeriksaan Tanggung Jawab dan Pengelolaan Keuangan Negara. Dengan adanya 3 (tiga) paket perundang-undangan tersebut telah memberikan implikasi pengelolaan keuangan negara yang terdesentralisasi, yang diwujudkan dalam suatu sistem yang transparan, akuntabel dan terukur.

Berdasarkan kondisi yang telah dipaparkan, penulis tertarik untuk meneliti dan menganalisa pengaruh karakteristik tujuan anggaran yang terdiri dari partisipasi dalam penyusunan anggaran, evaluasi anggaran, umpan balik anggaran, kejelasan tujuan anggaran, kesulitan sasaran anggaran, terhadap tingkat penyerapan anggaran, dimana pengawasan internal sebagai kontrol dari keseluruhan aktivitas yang berhubungan dengan keuangan dan daya serap anggaran.

\section{METODOLOGI PENELITIAN}

Penelitian ini menganalisa pengaruh karakteristik tujuan anggaran terhadap tingkat penyerapan anggaran pada UIN Syarif Hidayatullah Jakarta dengan dimoderasi pengawasan internal. Data dalam penelitian ini menggunakan kuesioner yang disebarkan kepada kepala bagian divisi dilingkungan UIN Syarif Hidayatullah Jakarta. Adapun penyebaraan dan 
pengembaliaan kuesioner dilaksanakan mulai tanggal 19 Agustus 2013 sampai 9 Oktober 2013.

Populasi penelitian ini adalah para pegawai di lingkungan UIN Syarif Hidayatullah Jakarta. Sampel pada penelitian ini adalah Kepala Sub Bagian (Kasubbag), Kepala Bagian (Kabag), Ketua Jurusan/Program Studi (Kajur/Kaprodi), Wakil Dekan (Wadek), Kepala Biro, Wakil Rektor (Warek) dan Satuan Pemeriksa Internal (SPI). Dasar pemilihan sampel ini menggunakan metode Convenience sampling. Metode ini dipilih karena peneliti diberi kemudahan untuk memilih sampel yang paling cepat serta adanya kesediaan dari respoden untuk menjawab setiap pertanyaan dari peneliti.

Metode pengumpulan data dipilih dengan riset lapangan yaitu dengan mendatangi langsung pada objek penelitian dengan menyerahkan kuesioner yang selanjutnya di follow up. Penelitian ini menggunakan data primer yaitu dengan cara mengumpulkan data melalui sejumlah pertanyaan yang diajukan kepada responden dengan cara mengisi kuesioner.

\subsection{Metode Analisis}

\section{Uji Hipotesis}

\section{a. Pengujian dengan Analisis Regresi Berganda}

Analisis regresi berganda digunakan sebagai alat untuk mengukur seberapa besar pengaruh antara variabel independen $(\mathrm{X})$ dengan variabel dependen $(\mathrm{Y})$. metode ini juga bisa dijadikan ramalan, sehingga dapat diperkirakan antara baik dan buruknya suatu variabel $(\mathrm{X})$ terhadap turunnya tingkat variabel $(\mathrm{Y})$, begitu juga sebaliknya. Analisis regresi ini mempunyai persamaan sebagai berikut: $\mathrm{Y}=\mathrm{a}+\mathrm{b}_{1} \mathrm{X}_{1}+\mathrm{b}_{2} \mathrm{X}_{2}+\mathrm{b}_{3} \mathrm{X}_{3}+\mathrm{b}_{4} \mathrm{X}_{4}+\mathrm{b}_{5} \mathrm{X}_{5}+\grave{\mathrm{e}}$

Uji statistik $\mathrm{t}$ menunjukkan apakah semua variabel independen atau bebas yang dimasukan dalam model mempunyai pengaruh secara individu terhadap variabel dependen atau terikat. Hipotesis alternatif yang hendak diuji adalah sebagai berikut:

$\mathrm{H}_{a 1}$ : Partisipasi penyusunan anggaran berpengaruh secara parsial dan signifikan terhadap tingkat penyerapan anggaran.

$\mathrm{H}_{\mathrm{a} 2}$ : Evaluasi anggaran berpengaruh secara parsial dan signifikan terhadap tingkat penyerapan anggaran.

$\mathrm{H}_{23}$ : Umpan balik anggaran berpengaruh secara parsial dan signifikan terhadap tingkat penyerapan anggaran.

$\mathrm{H}_{24}$ : Kejelasan sasaran anggaran berpengaruh secara parsial dan signifikan terhadap tingkat penyerapan anggaran.

$\mathrm{H}_{25}$ : Kesulitan sasaran anggaran berpengaruh secara parsial dan signifikan terhadap tingkat penyerapan anggaran. 
PENGARUH KARAKTERISTIK TUJUAN ANGGARAN...

Uji statistik F menunjukkan apakah semua variabel independen atau bebas yang dimasukan dalam model mempunyai pengaruh secara bersama-sama terhadap variabel dependen atau terikat (Ghozali, 2005:87). Hipotesis alternatif yang hendak diuji adalah sebagai berikut:

$\mathrm{H}_{\mathrm{a} 6}$ : Partisipasi penyusunan anggaran, evaluasi anggaran, umpan balik anggaran, kejelasan sasaran anggaran dan kesulitan sasaran anggaran berpengaruh secara simultan dan signifikan terhadap tingkat penyerapan anggaran.

\section{b. Pengujian dengan analisis regresi moderate (Moderate Regression Analysis -} MRA)

Uji interaksi atau sering disebut dengan Moderated Regression Analiysis (MRA) merupakan aplikasi khusus regresi berganda linier dimana dalam persamaan regeresinya mengandung unsur interaksi dengan rumus persamaannya sebagai berikut: (Ghozali, 2005:150)

$$
\begin{aligned}
Y= & a+b_{1} X_{1}+b_{2} X_{2}+b_{3} X_{3}+b_{4} X_{4}+b_{5} X_{5}+b_{6}\left(X_{1} Z\right)+b_{7}\left(X_{2} Z\right)+b_{8}\left(X_{3} Z\right) \\
& +b_{9}\left(X_{4} Z\right)+b_{10}\left(X_{5} Z\right)+\grave{e} \\
& \text { Hasil uji koefisien determinasi }\left(R^{2}\right) \text { mengukur seberapa besar kemampuan }
\end{aligned}
$$
model dalam menerangkan variasi variabel dependen. Nilai koofisien determinasi adalah antara nol dan satu (Ghozali, 2005:83).

Uji statistik t pada dasarnya menunjukkan seberapa jauh pengaruh satu variabel penjelas atau independen secara individual dalam menerangkan variasi variabel dependen (Ghozali, 2005:87). Hipotesis alternatif yang hendak diuji adalah sebagai berikut:

$\mathrm{H}_{\mathrm{a} 7}$ : Pengawasan internal akan memoderasi hubungan antara partisipasi penyusunan anggaran dan tingkat penyerapan anggaran

$\mathrm{H}_{a 8}$ : Pengawasan internal akan memoderasi hubungan antara evaluasi anggaran dan tingkat penyerapan anggaran

$\mathrm{H}_{a}$ : Pengawasan internal akan memoderasi hubungan antara umpan balik anggaran dan tingkat penyerapan anggaran

$\mathrm{H}_{\mathrm{a} 10}$ : Pengawasan internal akan memoderasi hubungan antara kejelasan sasaran anggaran dan tingkat penyerapan anggaran

$\mathrm{H}_{\text {a11 }}$ : Pengawasan internal akan memoderasi hubungan antara kesulitan sasaran anggaran dan tingkat penyerapan anggaran 


\section{ANALISIS DAN PEMBAHASAN}

3.1. Pengaruh partisipasi penyusunan anggaran terhadap tingkat penyerapan anggaran

Hasil uji menunjukkan bahwa variasi variabel partisipasi penyusunan anggaran hanya bisa menjelaskan 21,8\% variasi variabel tingkat penyerapan anggaran. Penelitian ini menunjukkan bahwa partisipasi penyusunan anggaran secara parsial tidak berpengaruh signifikan terhadap tingkat penyerapan anggaran karena tingkat signifikansi hasil uji t sebesar 0,848 .

\subsection{Pengaruh evaluasi anggaran terhadap tingkat penyerapan anggaran}

Hasil uji menunjukkan bahwa evaluasi anggaran secara parsial tidak berpengaruh signifikan terhadap tingkat penyerapan anggaran karena tingkat signifikansi hasil uji $\mathrm{t}$ sebesar 0,439 .

\subsection{Pengaruh umpan balik anggaran terhadap tingkat penyerapan anggaran}

Hasil uji menunjukkan bahwa umpan balik anggaran secara parsial berpengaruh signifikan terhadap tingkat penyerapan anggaran karena tingkat signifikansi hasil uji $\mathrm{t}$ sebesar 0,003.

\subsection{Pengaruh kejelasan sasaran anggaran terhadap tingkat penyerapan anggaran}

Hasil uji menunjukkan bahwa kejelasan sasaran anggaran secara parsial tidak berpengaruh signifikan terhadap tingkat penyerapan anggaran karena tingkat signifikansi hasil uji t sebesar 0,262.

\subsection{Pengaruh kesulitan sasaran anggaran terhadap tingkat penyerapan anggaran}

Hasil uji menunjukkan bahwa kejelasan sasaran anggaran secara parsial tidak berpengaruh signifikan terhadap tingkat penyerapan anggaran karena tingkat signifikansi hasil uji t sebesar 0,215.

3.6. Pengaruh partisipasi penyusunan anggaran, evaluasi anggaran, umpan balik anggaran, kejelasan sasaran anggaran dan kesulitan sasaran anggaran terhadap tingkat penyerapan anggaran.

Hasil uji hipotesis $\mathrm{H}_{6}$ menunjukkan bahwa partisipasi penyusunan anggaran, evaluasi anggaran, umpan balik anggaran, kejelasan sasaran anggaran dan kesulitan sasaran anggaran secara bersama-sama (simultan) berpengaruh signifikan terhadap tingkat penyerapan anggaran. Hasil uji memperlihatkan nilai Sig hasil uji $\mathrm{F}$ sebesar 0,000, sehingga dapat disimpulkan bahwa partisipasi penyusunan anggaran, evaluasi anggaran, umpan balik anggaran, kejelasan sasaran anggaran dan kesulitan sasaran anggaran secara simultan berpengaruh signifikan terhadap tingkat penyerapan anggaran. 
3.7. Pengawasan internal memoderasi hubungan antara partisipasi penyusunan anggaran dan tingkat penyerapan anggaran

Hasil uji interaksi menunjukkan bahwa pengawasan internal bukanlah variabel moderating antara partisipasi penyusunan anggaran dengan tingkat penyerapan anggaran karena tingkat signifikansi ZPPA sebesar 0,589.

3.8. Pengawasan internal memoderasi hubungan antara evaluasi anggaran dan tingkat penyerapan anggaran

Hasil uji interaksi menunjukkan bahwa pengawasan internal bukanlah variabel moderating antara evaluasi anggaran dengan tingkat penyerapan anggaran karena tingkat signifikansi ZEA sebesar 0,699.

3.9. Pengawasan internal memoderasi hubungan antara umpan balik anggaran dan tingkat penyerapan anggaran

Hasil uji interaksi menunjukkan tingkat signifikansi sebesar $0,016<0,05$, hal ini menandakan bahwa pengawasan internal bisa menjadi variabel moderating antara umpan balik anggaran dan tingkat penyerapan anggaran.

3.10. Pengawasan internal memoderasi hubungan antara kejelasan sasaran anggaran dan tingkat penyerapan anggaran

Hasil uji interaksi menunjukkan tingkat signifikansi sebesar $0,923>0,05$, hal ini menandakan bahwa pengawasan internal tidak bisa menjadi variabel moderating antara kejelasan sasaran anggaran dan tingkat penyerapan anggaran.

3.11. Pengawasan internal memoderasi hubungan antara kesulitan sasaran anggaran dan tingkat penyerapan anggaran

Hasil uji interaksi menunjukkan tingkat signifikansi sebesar $0,963>0,05$, hal ini menandakan bahwa pengawasan internal tidak bisa menjadi variabel moderating antara kesulitan sasaran anggaran dan tingkat penyerapan anggaran.

\section{KESIMPULAN}

Berdasarkan hasil penelitian diatas dapat disimpulkan:

a. Partisipasi penyusunan anggaran tidak berpengaruh secara signifikan terhadap tingkat penyerapan anggaran. Hasil uji menunjukkan bahwa partisipasi penyusunan anggaran secara parsial tidak berpengaruh secara signifikan terhadap tingkat penyerapan anggaran.

b. Evaluasi anggaran berpengaruh secara signifikan terhadap tingkat penyerapan anggaran. Hasil uji menunjukkan bahwa evaluasi anggaran secara parsial berpengaruh dan signifikan terhadap tingkat penyerapan anggaran. 
c. Umpan balik anggaran berpengaruh secara signifikan terhadap tingkat penyerapan anggaran. Hasil uji menunjukkan bahwa umpan balik anggaran secara parsial berpengaruh dan signifikan terhadap tingkat penyerapan anggaran.

d. Kejelasan sasaran anggaran berpengaruh secara signifikan terhadap tingkat penyerapan anggaran. Hasil uji menunjukkan bahwa kejelasan sasaran anggaran secara parsial berpengaruh dan signifikan terhadap tingkat penyerapan anggaran.

e. Kesulitan sasaran anggaran berpengaruh secara signifikan terhadap tingkat penyerapan anggaran. Hasil uji menunjukkan bahwa kesulitan sasaran anggaran secara parsial berpengaruh dan signifikan terhadap tingkat penyerapan anggaran.

f. Partisipasi penyusunan anggaran, evaluasi anggaran, umpan balik anggaran, kejelasan sasaran anggara dan kesulitan sasaran anggaran berpengaruh secara simultan dan signifikan terhadap tingkat penyerapan anggaran.

g. Pengawasan internal tidak dapat dijadikan sebagai variabel moderating antara partisipasi penyusunan anggaran dan tingkat penyerapan anggaran. Hasil uji interaksi menunjukkan bahwa pengawasan internal bukanlah variabel moderating antara partisipasi penyusunan anggaran dengan tingkat penyerapan anggaran.

h. Pengawasan internal dapat dijadikan sebagai variabel moderating antara evaluasi anggaran dan tingkat penyerapan anggaran. Hasil uji interaksi menunjukkan bahwa pengawasan internal merupakan variabel moderating antara evaluasi anggaran dengan tingkat penyerapan anggaran.

i. Pengawasan internal dapat dijadikan sebagai variabel moderating antara umpan balik anggaran dan tingkat penyerapan anggaran. Hasil uji interaksi menunjukkan bahwa pengawasan internal merupakan variabel moderating antara umpan balik anggaran dengan tingkat penyerapan anggaran.

j. Pengawasan internal dapat dijadikan sebagai variabel moderating antara kejelasan sasaran anggaran dan tingkat penyerapan anggaran. Hasil uji interaksi menunjukkan bahwa pengawasan internal merupakan variabel moderating antara kejelasan sasaran anggaran dengan tingkat penyerapan anggaran.

k. Pengawasan internal dapat dijadikan sebagai variabel moderating antara kesulitan sasaran anggaran dan tingkat penyerapan anggaran. Hasil uji interaksi menunjukkan bahwa pengawasan internal merupakan variabel moderating antara kesulitan sasaran anggaran dengan tingkat penyerapan anggaran. 
PENGARUH KARAKTERISTIK TUJUAN ANGGARAN...

\section{REFERENSI}

Andriyanto, Yogi. 2008. Analisis Pengaruh Partisipasi Penyusunan Anggaran Terbadap Kinerja Manajerial Dengan Kepuasan Kerja, Job Relevant Information dan Kepuasan Kerja Sebagai Variabel Moderating (Studi Empiris Pada Rumah Sakit Swasta Di Wilayah Kota Semarang), Tesis Magister, Universitas Diponegoro, Semarang.

Arif, Bahtiar, Muchlis dan Iskandar. 2002. Akuntansi Pemerintahan, Edisi Pertama, Penerbit Salemba Empat, ISBN:979-691-106-X, Jakarta.

Bangun, Andarias. 2009. Pengaruh Partisipasi Dalam Penyusunan Anggaran, Kejelasan Sasaran Anggaran dan Struktur Desentralisasi Terbadap Kinerja Manajerial SKPD Dengan Pengawasan Internal Sebagai Variabel Moderating (Studi Kasus Pada Pemerintah Kabupaten Deli Serdang), Tesis Magister, Universitas Sumatera Utara, Medan.

Bawono Bayu Dwi Andy. 2009. Pengaruh Budgetary Goal Characteristic Sebagai Variabel Intervening Dalam Hubungan Antara Keadilan Prosedural dan Kinerja Manajerial (Studi Pada Pejabat Eselon III dan IV Pada Pemerintah Daerah se-Eks Karesidenan Surakarta), Tesis Magister, Universitas Diponegoro, Semarang.

Brownell, Petter and Morris. 1983. Budgetary Participation, Motivation and Managerial Performance, Working Paper, Alfred P. Sloan School of Management, Massachusetts, Institute of Technology, 50 Memorial Drive, Cambridge, Massachusetts 02139, Wp 1389-83, January 1983.

Ferdinand A. Gul, Judy S. L. Tsui, Steve C. C. Fong and Helen Y. L. Kwok. 1995. Decentralisation as a Moderating Factor in the Budgetary Participation-Performance Relationship: Some Hong Kong Evidence, Accounling and Business Research. Vol. 25. No. 98, pp. 107113.

Ghozali, Imam. 2005. Aplikasi Analisis Multivariate dengan Program SPSS, Edisi 3, Badan Penerbit Universitas Diponegoro, Semarang.

Indriantoro, Nur dan Bambang Supomo. 2002. Metodologi Penelitian Bisni, Yogyakarta: Edisi Pertama Cet. Ke-2, BPFE.

Jalaluddin, Bahri Dafi. 2009. Pengaruh Partisipasi Anggaran, Kejelasan Tujuan Anggaran dan Evaluasi Anggaran Terbadap Kinerja Aparat Pemerintah Daerah (Studi Empiris Pada Satuan Kerja Pemerintah Daerah Kota Banda Aceh), Jurnal Telaah dan Riset Akuntansi, Vol. 2, No. 1. Hal 44-53, Januari 2009.

Kennis,I. 1979. Effect of Budgetary Goal Characteristic on Managerial Attitudes and Performance, The Accounting Revien: 707-721.

Majalah Keuangan Sektor Publik, Warta Anggaran. 2011. Kesiapan Indonesia Hadapi Krisis Ekonomi Global, www.Anggaran.depkeu.go.id.Edisi 23 Tahun 2011. 
Mardiasmo. 2002. Akuntansi Sektor Publik, Penerbit C.V. Andi Offset, 218 Hlm, ISBN:979-763084-7, Yogyakarta.

Melek, Eker. 2012. The Impact Of Budget Participation On Managerial Performance Via Organizational Commitment: A Study On The Top 500 Firms In Turkey, Ankara- University.

Munawar, Irianto Gugus, Nurkholis dan Politeknik Negeri Kupang. 2006. Pengarub Karakteristik Tujuan Anggaran Terhadap Perilaku, Sikap dan Kinerja Aparat Pemerintah Daerah Di Kabupaten Kupang, Fakultas Ekonomi, Universitas Brawijaya, Malang, Simposium Nasional Akuntansi 9 Padang.

Noerdiawan, Deddi. 2009. Akuntansi Sektor Publik, Penerbit Salemba Empat, 234 Hal, ISBN:978-979-691-322-4, Jakarta.

Nurul, Ria dan Enni. 2012. Pengarub Partisipasi Penyusunan Anggaran, Kejelasan Sasaran Anggaran, Kesulitan Sasaran Anggaran, Evaluasi Anggaran dan Umpan Balik. Anggaran Terhadap Kinerja Manajerial, nurul_nb@yahoo.com.

Othman, Radiah. 2012. Budgetary Participation: How It Affects Performance and Commitment, Accounting Business and The Public Interest, Senior Lecturer, School of Accountancy, College of Business, Massey University, New Zealand.

Peraturan Menteri Pendidikan Nasional Republik Indonesia No. 47 Tahun 2011 tentang Satuan Pengawasan Intern di Lingkungan Kementerian Pendidikan Nasional.

Puspaningsih Abriyani. 2003. Pengaruh Partisipasi Dalam Penyusunan Anggaran Terhadap Kepuasan Kerja dan Kinerja Manajer: Role Ambignity Sebagai Variabel Antara, JAAI Volume 7 No. 2, Desember 2003.

Putra, Firdos dan Edy Rawuh. 2012. Mengurai Sindrom Akbir Tabun Anggaran, Magister Ilmu Administrasi, Universitas Jenderal Soedirman, Telah Dipreseentasikan Pada Simposium Nasional Asosiasi Ilmuwan Administrasi Negara, (SIMNAS ASIAN) ke-2, Universitas Slamet Riyadi, Surakarta, 10 Pebruari 2012.

Ramandei, Pilipus. 2009. Pengaruh Karakterisstik Sasaran Anggaran dan Sistem Pengendalian Intern Terbadap Kinerja Manajerial Aparat Pemerintah Daerah (Studi Empiris Pada Satuan Kerja Perangkat Daerah Kota Jayapura), Tesis Magister, Universitas Diponegoro, Semarang.

Santosa, Budi, 2005. Analisis Statistik dengan Microsoft Excel dan SPSS, Penerbit Andi Offset, 282 Hlm, ISBN: 979-731-717-X, Yogyakarta.

Suhartono, Ehrmann dan Solichin Mochammad. 2006. Pengaruh Kejelasan Sasaran Anggaran Terhadap Senjangan Anggaran Instansi Pemerintah Daerah Dengan Komitmen Organisasi Sebagai Pemoderasi, Fakultas Ekonomi, Universitas Teknologi, Yogyakarta, Simposium Nasional Akuntansi 9 Padang, 23-26 Agustus 2006. 
PENGARUH KARAKTERISTIK TUJUAN ANGGARAN...

Tjandra, Mathilda. 2008. Pengarub Partisipasi Dalam Penyusunan Anggaran Terhadap Kinerja Manajerial Dengan Reward Sebagai Variabel Moderating Pada Asian Agri Group, Tesis Magister, Universitas Sumatera Utara, Medan.

Warta Pengawasan. 2012. Membangun Good Governance Menuju Clean Government. Mencari Solusi Bagi Serapan Yang Tersumbat, Warta Pengawasan Vol. XIX/No.1/Maret 2012.

Yuwono, Soni, Tengku dan Hariyandi. 2005. Penganggaran Sektor Publik, Pedoman Praktis Penyusunan, Pelaksanaan, dan Pertanggungjawaban APBD (Berbasis Kinerja), telah Disesuaikan dengan PP No. 24/2005 tentang Standar Akuntansi Pemerintahan, Cetakan Pertama, Penerbit Bayumedia Publishing, ISBN:979-3695-49-8, Malang, Jawa Timur. 